\title{
Is Phytomelatonin a New Plant Hormone?
}

\author{
Marino B. Arnao *(1) and Josefa Hernández-Ruiz \\ Department of Plant Biology (Plant Physiology), Faculty of Biology, University of Murcia, 30100 Murcia, Spain; \\ jhruiz@um.es \\ * Correspondence: marino@um.es
}

Received: 29 November 2019; Accepted: 7 January 2020; Published: 9 January 2020

\begin{abstract}
Melatonin ( $\mathrm{N}$-acetyl-5-methoxytryptamine) is of particular importance as a chronobiological hormone in mammals, acting as a signal of darkness that provides information to the brain and peripheral organs. It is an endogenous synchronizer for both endocrine (i.e., via neurotransmitter release) and other physiological rhythms. In this work we will try to add to the series of scientific events and discoveries made in plants that, surprisingly, confirm the great similarity of action of melatonin in animals and plants. The most relevant milestones on the 25 years of phytomelatonin studies are presented, from its discovery in 1995 to the discovery of its receptor in plants in 2018, suggesting it should be regarded as a new plant hormone.
\end{abstract}

Keywords: biological clock; melatonin; photosynthesis; phytomelatonin; plant hormone; plant stress; redox network

\section{Introduction}

Melatonin ( $N$-acetyl-5-methoxytryptamine) was discovered in 1958 in the pineal gland of a cow by Lerner and cols. [1]. This isolated, active factor lightens skin color in frogs, tadpoles, toads and certain fish, but not in mammals, as a consequence of the aggregation of melanin granules of melanocytes. For this reason, the authors proposed that the substance be called melatonin, and it was chemically identified in 1959 as a derivative of $N$-acetylserotonin [2].

Melatonin is of particular importance as a chronobiological hormone, acting as a signal of darkness that provides information to the brain and peripheral organs. It is an endogenous synchronizer for both endocrine (i.e., via neurotransmitter release) and other physiological rhythms, regulating sleep-wake cycles and synchronizing life activity into seasonal periods and reproductive functions [3-11].

Melatonin plays an important role in the regulation of sleep, body temperature, the state of alertness and degree of concentration or performance, and cortisol rhythms. It acts as a sleep initiator by opening the circadian sleep gate, thus acting as a sleep regulator. Melatonin adjusts the timing of or reinforces the oscillators of the central biological clock. The administration of exogenous melatonin alters the timing of bodily rhythms, including sleep, whereby phase delays are observed with the morning administration of melatonin, while phase advances are found after evening administration [12]. Many sleep disorders have been treated with melatonin: delayed sleep phase syndrome, night shift work sleep disorder, seasonal affective disorder, sleep disorders in the blind and ageing, and pathophysiological disorders of children, with notable improvements in "sleep quality" [13]. The most common disorder treated with melatonin is jet lag, a de-phasing in the sleep-wake rhythms caused by transoceanic flights [14-16].

In mammals, melatonin is secreted by the pineal gland to the cerebrospinal fluid and to the bloodstream, presenting maximal levels during the middle of the night. This circadian pattern of melatonin secretion is regulated by the biological clock that resides in mammals within the hypothalamic suprachiasmatic nucleus (SCN) [17]. The SCN is synchronized to the environmental light-dark cycle by the light perceived by the retina. Also, the $\mathrm{SCN}$ regulates pineal secretion through a polysynaptic 
network in the paraventricular nucleus of the hypothalamus [18]. Melatonin release occurs when the noradrenaline released by paraventricular nucleus fibers activate the pineal $\beta$-adrenergic receptors, stimulating, via cyclic AMP (adenosine 3-phosphate), the expression of serotonin $N$-acetyltransferase (SNAT), a key enzyme of melatonin biosynthesis, in the dark. Brief exposure to light provokes a decrease in melatonin production because of the degradation of SNAT in the pineal gland [19-21].

Until recently, it was thought that this whole process and situation had nothing to do with plant systems, and no coincidence of action was suspected. As will be seen later, the discovery of melatonin in plants, called phytomelatonin, has meant a considerable change in studies of many aspects of plant physiology. Thus, phytomelatonin has been involved in aspects such as germination, growth, rooting, fruiting, parthenocarpy, maturation, and in post-harvest. It has also been studied in key processes, such as primary/secondary metabolism, photosynthesis, senescence and $\mathrm{CO}_{2}$ intake, and in the nitrogen, phosphorus, and sulfur cycles. Also, one of the most decisive aspects has been its recognized role as a protective and alleviating agent against stressors, both biotic and abiotic. This last aspect has opened a great field of action to be able to use melatonin in agricultural treatments, such as phytoprotective and biostimulant. However, below we will try to explain the series of scientific events and discoveries in plants that, surprisingly, testify to the great similarity of action of melatonin in animals and plants. In this respect, we explain the most relevant milestones of phytomelatonin for it to be considered as a new plant hormone.

\section{Topics of the First Fifteen Years}

As with most of the discoveries made concerning classical plant hormones, the story of events begins with its detection in plant tissues, its metabolism and regulation, the possible cellular and physiological functions, and, finally, the discovery of its receptor(s) and its action mechanism and regulation. In this respect, we recommend consulting the excellent special issue entitled History of Plant Hormone Research, edited by Lüthen and Ludwig-Müller (2015), for some relevant details concerning the discovery of auxin, gibberellins, cytokinins, abscisic acid, ethylene, jasmonates, and brassinosteroids [22].

Until 1995, melatonin was exclusively thought to be an animal hormone and it was one of the molecules that had been most researched and written on in the scientific press, in specialized journals, such as Journal of Pineal Research, established in 1984, and the most recent Melatonin Research. But then, in 1995, three independent research groups published the unequivocal identification of melatonin in plants [23-25]. This data caused uncertainty since the presence of an animal hormone in plant tissues was unsuspected. Since this time, successive studies have quantified the presence of melatonin in plants, and it is now fully accepted that melatonin is present in all kingdoms, from prokaryotes to eukaryotes, from animals to plants. Melatonin of plant origin is called phytomelatonin [26]. In the first years following its discovery in plants, the research focused on physiological roles similar to those that melatonin was known to have in animals. Table 1 compiles the most relevant publications in the period 1995-2009. Thus, one of the first objectives was to demonstrate its possible participation as a chrono-regulatory molecule in photomorphogenic processes, such as flowering. The Czech group of Drs. Kolář and Macháčková spent many years attempting to demonstrate the role of phytomelatonin in the flowering of Chenopodium rubrum $\mathrm{L}$. and the influence of circadian rhythms in phytomelatonin levels, unfortunately without conclusive results [27-30]. Another interesting line of work was that developed by the group of Dr. Saxena in Canada. By 2000, working with cells in culture of St John's wort (Hypericum perforatum L.), they already had determined steps in the phytomelatonin biosynthesis pathway that were similar to those of animals, and they proposed that melatonin could act as an auxin in in vitro cell cultures due to the chemical similarity between the molecules melatonin and indole-3-acetic acid (IAA) (Sigma Co, Madrid, Spain) [31-33]. In 2004, using etiolated lupin (Lupinus albus L.) hypocotyls, it was first demonstrated that melatonin had a growth-stimulating effect, and its stimulatory potential was valued at up to $63 \%$ with respect to the effect of IAA [34]. This growth stimulating effect was subsequently confirmed in several species of Poaceae. The double 
growth-stimulating and inhibitory effect dependent on the concentration and the tissue tested (aerial or root zone), similar to that which occurs using IAA, was also demonstrated [35,36]. Also, in 2004, the first paper on the protective role of melatonin in carrot (Daucus carota L.) cells under cold stress was published [37]. In 2008, the effect of the melatonin-inducing germination of Brassica oleracea L. seeds under copper toxicity opened the door for numerous studies with the objective of demonstrating the protective effect of melatonin [38,39]. This protective effect of melatonin against diverse abiotic (drought, salinity, waterlogging, cold, heat, metal toxics, herbicides, UV radiation) and biotic (bacteria, fungi, virus) stressors has been the most widely studied aspect, featuring in numerous species and experimental situations that were all of high agronomic relevance [40-51].

Another important role for melatonin was suggested in 2007, when it was shown that melatonin could stimulate the formation of both true and adventitious roots in lupin, stimulating the formation of root primordiae in the pericycle [52].

In 2009, another aspect of great relevance was suggested for melatonin. Barley leaves incubated with melatonin clearly retarded their loss of dark-induced chlorophylls [53]. It was later shown that, in leaf senescence, melatonin regulates transcription factors linked to senescence and chlorophyll metabolism [54]. Also, in 2009, the role of melatonin in stress situations was demonstrated, since an increase in endogenous phytomelatonin levels was recorded in a variety of stress situations, accompanied by a consequent anti-stress response [55]. All induced stresses activate the biosynthesis of phytomelatonin in tissues and are generally associated with a burst in reactive oxygen and nitrogen species (ROS/RNS). Induced stresses also up regulate the gene expression of the melatonin biosynthesis enzymes tryptophan 5-hydroxylase (T5H), tryptophan decarboxylase (TDC), serotonin $N$-acetyltransferase (SNAT), acetylserotonin methyltransferase (ASMT) and caffeic acid O-methyltransferase (COMT) $[42,47,56]$.

Table 1. Most relevant studies on melatonin in plants in the period 1995-2009.

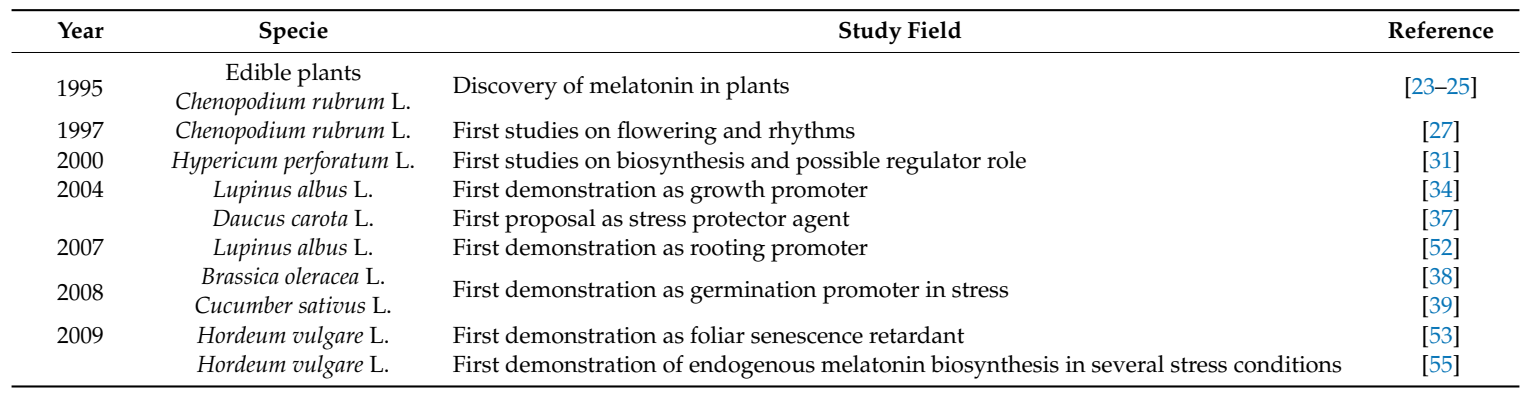

Outside the field of plant physiology, this period saw the first papers on the effect of human plasma on the consumption of fruits and vegetables rich in phytomelatonin, and the beneficial effects on the antioxidant status and improvements in sleep parameters were described [57-61].

This first exciting period (1995-2009) was characterized by the search for the unknown effects of melatonin in plants, sometimes based on existing knowledge of its role in animals, but on many other occasions as a result of unexpected discoveries. Figure 1 illustrates the evolution in the number of articles (papers and others) published on melatonin in plants. As can be seen from the first articles published in 1995, only 35 articles were published up to 2005 (an average of 3.2 per year). Since 2010, the publications on melatonin in plants have shown an exponential increase, reaching a maximum in 2019 with 88 articles. It is expected that in the forthcoming years, this number may well be exceeded. 


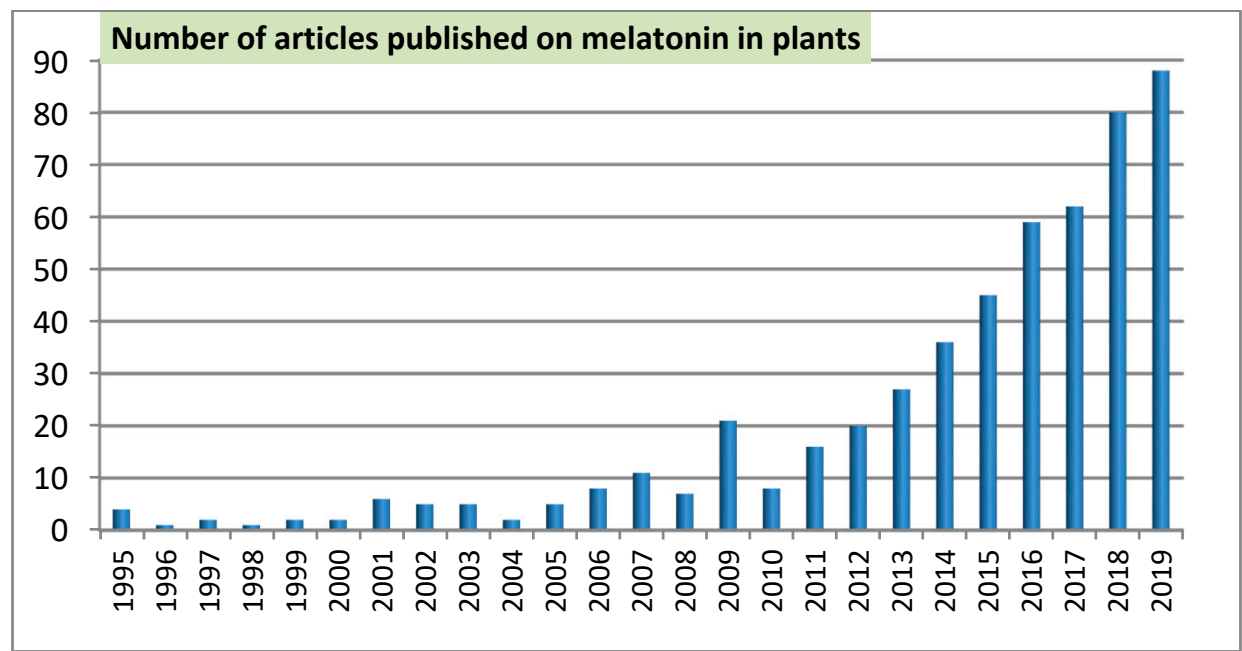

Figure 1. Evolution of the number of articles related with melatonin in plants since its discovery in 1995. For 2019, the data are based on an extrapolation of the data available to date (first 10 months).

\section{Current Topic Status}

The period from 2010 to the present has been very productive in terms of achievements. During this time, many of the ideas that were only suggested in the previous period have been demonstrated, and there is a very active and enthusiastic research body. Table 2 shows the most outstanding events in this second period.

In this period, many more phytomelatonin determinations/quantifications have been made by studying the phytomelatonin content of many plant species, both edible and wild type, and in various plant organs (roots, leaves, stems, flowers, fruits, and seeds). The same is true for foods of plant origin and their processed and fermented products (juices, musts, wines, infusions, etc.). Additionally, many suggestions have been made regarding its nutraceutical potential [26,62-70].

The phytomelatonin biosynthesis route has been completed with great accuracy, mainly due to the works of Dr. K. Back and his team, in rice and Arabidopsis plants [71-83]. One aspect of great interest has been the discovery that some melatonin catabolites, such as 2-hydroxymelatonin, also have physiological activity, a topic that merits further study [84-88]. 
Table 2. Pioneering studies on melatonin in plants in the period 2010-2019.

\begin{tabular}{|c|c|c|}
\hline Year & Study Field & Reference \\
\hline 2010-2018 & Biosynthesis and catabolic route & {$[83,89]$} \\
\hline 2012 & Confirmation that melatonin induces lateral rooting independent of auxin signal & [90] \\
\hline 2013 & Growth conditions determine endogenous phytomelatonin level & [91,92] \\
\hline 2013-2014 & Melatonin determines many changes in gene expression & {$[93,94]$} \\
\hline 2012-2013 & Melatonin positively affects chlorophyll and carotenoid levels, photosynthesis, water economy, carbon, nitrogen, sulfur and phosphorous metabolism and secondary metabolism & [54,95-101] \\
\hline 2013-2014 & Melatonin improves resistance to plant diseases and activates the immune response & [102-104] \\
\hline 2014 & Many stress response factors are activated by melatonin & {$[105,106]$} \\
\hline 2014-2015 & Plant hormone gene expression is regulated by melatonin & {$[104,107,108]$} \\
\hline 2015 & Melatonin induces the nitric oxide pathway in innate immunity pathogen infection & [109] \\
\hline 2015-2016 & Melatonin regulates its own biosynthesis genes (SNAT, ASMT and COMT) & {$[108,110]$} \\
\hline 2016 & Melatonin levels are regulated by diurnal cycles and it is related with biological clock and stress gene elements & [111] \\
\hline 2015-2017 & Melatonin improves the quality of fruits and flowers during post-harvest & [112-115] \\
\hline 2018 & Melatonin induces parthenocarpy & [116] \\
\hline 2018 & First phytomelatonin receptor (PMTR1) is identified and characterized & [117] \\
\hline 2019 & Melatonin aids in the eradication of apple stem grooving virus & [118] \\
\hline
\end{tabular}


The physiological aspects in which melatonin exerts some beneficial action are shown in Figure 2 and are commented on below:

- Improvements in photosynthesis efficiency, preserving chlorophylls and carotenoids, reducing photorespiration, stomatic conductance and optimizing water economy; improving the yield of seeds and fruits in adverse conditions. Osmoregulation balance, the regulation of ion exchange and adjustments of osmotic and water potentials.

- The regulation of the different metabolisms of carbohydrates, lipids, nitrogen compounds, and sulfur and phosphorus cycles; the induction of the biosynthesis of flavonoids, anthocyanins, and carotenoids, among others, in the secondary metabolism, generally in stress conditions.

- In hormonal homeostasis, interventions in the regulation of all plant hormones, up- or down-regulating the gene biosynthesis/catabolic expression of auxin (IAA), cytokinins (CKs), gibberellins (GAs), abscisic acid (ABA), salicylic acid (SA), jasmonic acid (JA), ethylene, brassinosteroids, strigolactone, and polyamines.

- Melatonin regulates its own biosynthesis, upregulating the gene expression of phytomelatonin biosynthesis genes, mainly SNAT, ASMT, and COMT.

- Melatonin levels are regulated by diurnal cycles in Arabidopsis and it is related with CIRCADIANCLOCK ASSOCIATED 1 (CCA1), a main biological clock of elements. Also, $C$-repeat-binding factors (CBFs)/Drought response element Binding 1 factors (DREB1s) were co-regulated by exogenous melatonin and diurnal changes, indicating the possible correlation among clock, endogenous melatonin level, AtCBFs expressions, and plant immunity.

- In the rooting processes of primary, secondary and adventitious roots, melatonin regulates the expression of many factors, such as PIN auxin transporters and AUX1, among others.

- In the processes of foliar senescence, melatonin regulates the expression of chlorophyll degradation-related and senescence-induced genes.

- In the post-harvest control of fruits, melatonin increases the ethylene and lycopene content, and regulates many enzymes of the cell wall, ethylene biosynthesis and of the primary and secondary metabolism. It also helps preserve cut flowers.

- Melatonin induces parthenocarpy in pear, increasing GAs level.

- Of great importance is its role in bacterial, fungal, and viral pathogen infections, with relevant responses, slowing damage and stimulating systemic acquired resistance (SAR), to favor crop health.

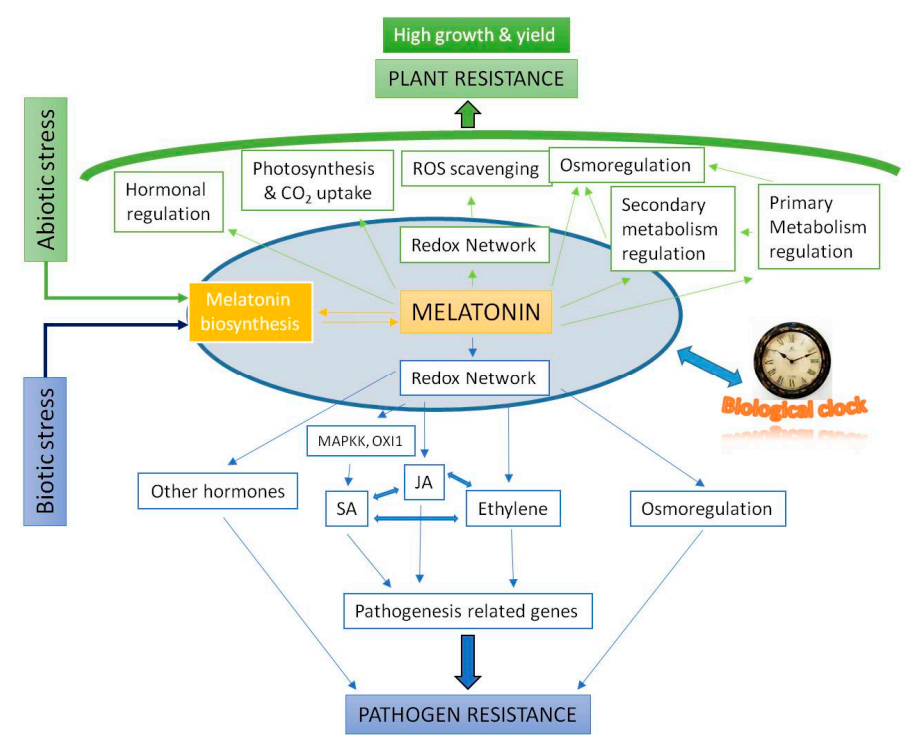

Figure 2. Model of phytomelatonin action regulating redox network in abiotic and biotic stress responses. 
Figure 2 shows an overview of the protective role of phytomelatonin against abiotic and biotic stressors. Melatonin acts as a master regulator of the redox network, activating many responses mainly through the nitric oxide pathway, among others. Several recent reviews can be consulted $[42,43,46-51,56,119-124]$.

\section{Aspects that Lead One to Consider Melatonin as a New Plant Hormone}

The first proposals about the possible role of phytomelatonin concerned its antioxidant potential. Chemically, melatonin is an excellent antioxidant, presenting an antioxidant potential many times greater than classical antioxidants, such as ascorbic acid, vitamin E, and others. Its capacity as a regulator of gene expression soon opened the door to new hypotheses. For a molecule to be considered as a plant hormone implies knowledge of its biosynthesis, degradation, possible conjugation, transport, receptor(s), signal transduction chain, and physiological effect(s). Many of these requisites were well documented, but the detection of a phytomelatonin receptor proved more elusive [42,56], and it was not until 2018 that Dr. Chen's group first detected and characterized the phytomelatonin receptor called PMTR1. Localized in the plasma membrane of Arabidopsis thaliana, it presents a receptor-like topology. It interacts with the G-protein a subunit (GPA1), while its expression in different tissues can be induced by melatonin. PMTR1-phytomelatonin binding triggers the dissociation of $G \gamma b$ and $G \alpha$, which activates a NADPH oxidase-dependent $\mathrm{H}_{2} \mathrm{O}_{2}$ production $(\mathrm{RBOH})$, enhancing $\mathrm{Ca}^{2+}$ influx and promoting $\mathrm{K}^{+}$efflux, all of which finally results in stomatal closure [117]. This was a crucial step for starting to consider the hormone nature of phytomelatonin. However, the consequent description of the phytomelatonin receptor in other plant species also seems to be an essential requirement. It was known that phytomelatonin exerted a regulatory role on the redox network, mobilizing a large amount of genetic resources in stress situations to restore redox homeostasis. Some detailed models, in which phytomelatonin is considered as a plant master regulator of the redox network, have been suggested $[42,47,56,124]$. In Figure 3 we proposed a model in which core clock, phytomelatonin and the receptor PMRT1 are integrated in the coordination and response to the redox network. Although there are data on the role of phytomelatonin as a chronoregulator in plants [41,111], this piece of the puzzle between biological clock and redox network, is yet to be confirmed experimentally, with researchers currently in its study. If this last idea is confirmed, phytomelatonin worked in transferring biological clock oscillations to the redox network and, as a plant master regulator (plant master hormone), provides the adequate response to reach redox homeostasis in stress situations, in a similar way to animal melatonin.

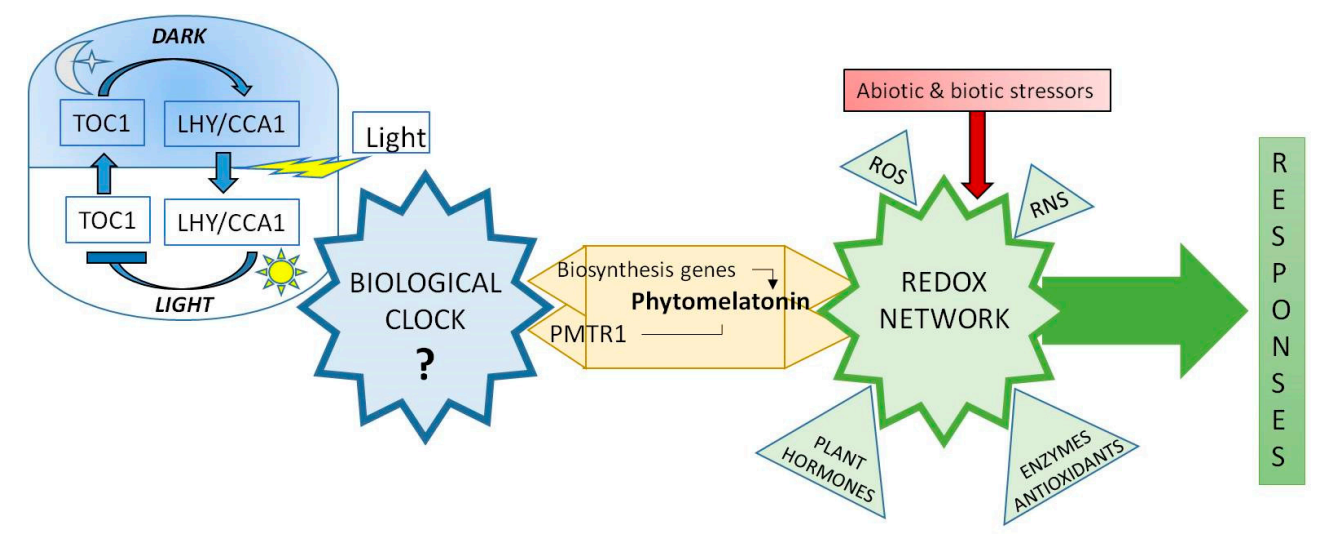

Figure 3. Possible relationship of the triad: core biological clock-Phytomelatonin-Redox network.

\section{Perspectives}

Since the discovery of phytomelatonin in plants 25 years ago, much progress has been made in improving our knowledge. Its possible role as a chronobiological plant hormone, coordinating the biological clock with redox homeostasis, can explain its importance in stress responses and in regulating 
the levels of other plant hormones in many actions. It also explains its role in the optimization of the photosynthetic system, including the aspects of water economy and the assimilation of $\mathrm{CO}_{2}$, all of which are regulated by the biological clock.

However, all of the above lead to more questions and objectives, such as: what changes does exogenous melatonin treatment cause in the triad core clock-phytomelatonin-redox network? And what changes does it cause in the stress agents? Is there only one type of receptor for phytomelatonin? And does this regulatory triad exist in other species? In CAM (Crassulaceae Acid Metabolism) plants, which open their stomata at night, what differences exist from the model described for Arabidopsis? The answers to these and many other questions will throw further light on the fascinating world of this universal molecule.

Author Contributions: M.B.A. conceived and designed the manuscript. M.B.A. and J.H.-R. wrote and approved the revision of manuscript. All authors have read and agreed to the published version of the manuscript.

Funding: This research received no external funding.

Conflicts of Interest: The authors declare no conflicts of interest.

\section{Abbreviations}

$\begin{array}{ll}\text { AUX1 } & \text { auxin transporter-like protein } \\ \text { ASMT } & \text { N-acetylserotonin methyltransferase } \\ \text { CAM } & \text { Crassulaceae acid metabolism } \\ \text { CCA1 } & \text { circadian clock associated-1 } \\ \text { COMT } & \text { caffeoyl-O-methyl transferase } \\ \text { GAs } & \text { gibberellins } \\ \text { IAA } & \text { indole-3-acetic acid } \\ \text { LHY } & \text { late elongated hypocotyl } \\ \text { PIN } & \text { auxin efflux transporters } \\ \text { PMTR1 } & \text { phytomelatonin receptor } \\ \text { RBOH } & \text { NADPH oxidase-dependent } \mathrm{H}_{2} \mathrm{O}_{2} \text { production } \\ \text { RNS } & \text { reactive nitrogen species; ROS, reactive oxygen species } \\ \text { SAR } & \text { systemic acquired resistance } \\ \text { SCN } & \text { suprachiasmatic nucleus } \\ \text { SNAT } & \text { serotonin } N \text {-acetyltransferase } \\ \text { T5H } & \text { tryptophan 5-hydroxylase } \\ \text { TDC } & \text { tryptophan decarboxylase } \\ \text { TOC1 } & \text { timing of CAB expression-1 }\end{array}$

\section{References}

1. Lerner, A.B.; Case, J.D.; Takahashi, Y.; Lee, T.H.; Mori, W. Isolation of melatonin, a pineal factor that lightens melanocytes. J. Am. Chem. Soc. 1958, 80, 2587. [CrossRef]

2. Reiter, R.J. The melatonin rhythm: Both a clock and a calendar. Experientia 1993, 49, 654-664. [CrossRef]

3. Lerner, A.; Case, J.; Heinzelmann, R. Structure of melatonin. J. Am. Chem. Soc. 1959, 81, 6084-6085. [CrossRef]

4. Horacio, O.D.L.; Meyer, J.; Carpino, A.J.; Schwartz, W.J. Antiphase oscillation of the left and right suprachiasmatic nuclei. Science 2000, 290, 799-801.

5. Reppert, S.M.; Weaver, D.R. Coordination of circadian timing in mammals. Nature 2002, 418, $935-941$. [CrossRef]

6. Perreau-Lenz, S.; Kalsbeek, A.; Garidou, M.L.; Wortel, J.; van der Vliet, J.; van Heijningen, C.; Simonneaux, V.; Pévet, P.; Buijs, R.M. Suprachiasmatic control of melatonin synthesis in rats: Inhibitory and stimulatory mechanisms. Eur. J. Neurosci. 2003, 17, 221-228. [CrossRef] [PubMed]

7. Saper, C.B.; Scammell, T.E.; Lu, J. Hypothalamic regulation of sleep and circadian rhythms. Nature 2005, 437, 1257-1263. [CrossRef] [PubMed]

8. Fuller, P.M.; Gooley, J.J.; Saper, C.B. Neurobiology of the sleep-wake cycle: Sleep architecture, circadian regulation, and regulatory feedback. J. Biol. Rhythm. 2006, 21, 482-493. [CrossRef] 
9. Jan, J.E.; Reiter, R.J.; Wasdell, M.B.; Bax, M. The role of the thalamus in sleep, pineal melatonin production, and circadian rhythm sleep disorders. J. Pineal Res. 2009, 46, 1-7. [CrossRef] [PubMed]

10. Agathokleous, E.; Kitao, M.; Calabrese, E.J. New insights into the role of melatonin in plants and animals. Chem. Bioll. Interact. 2019, 299, 163-167. [CrossRef]

11. Zhao, D.; Yu, Y.; Shen, Y.; Liu, Q.; Zhao, Z.; Sharma, R.; Reiter, R.J. Melatonin synthesis and function: Evolutionary history in animals and plants. Front. Endocrinol. 2019, 10, 249. [CrossRef] [PubMed]

12. Lewy, A.J.; Ahmed, S.; Jackson, J.M.; Sack, R.L. Melatonin shifts human ciracadian rhythms according to a phase-response curve. Chronobiol. Int. 1992, 9, 380-392. [CrossRef] [PubMed]

13. Arnao, M.B.; Hernández-Ruiz, J. Melatonin: Synthesis from tryptophan and its role in higher plants. In Amino Acids in Higher Plants; D’Mello, J.P.F., Ed.; CAB Intern: Boston, MA, USA, 2015; pp. 390-435.

14. Waterhouse, J.; Reilly, T.; Atkinson, G. Jet-lag. Lancet 1997, 350, 1611-1616. [CrossRef]

15. Takahashi, T.; Sasaki, M.; Itoh, H.; Ozone, M.; Yamadera, W.; Hayshida, K.I.; Ushijima, S.; Matsunaga, N.; Obuchi, K.; Sano, H. Effect of $3 \mathrm{mg}$ melatonin on jet lag syndrome in an 8-h eastward flight. Psychiatry Clin. Neurosci. 2000, 54, 377-378. [CrossRef] [PubMed]

16. Herxheimer, A. Jet lag. Clin. Evid. 2005, 13, 2178-2183.

17. Klein, D.; Moore, R. Pineal N-acetyltransferase and hydroxiindole-O-methyltransferase: Control by the retinohypothalamic tract and the suprachiasmatic nucleus. Brain Res. 1979, 174, 245-262. [CrossRef]

18. Buijs, R.; Hermes, M.; Kalsbeek, A. The suprachiasmatic nucleus-paraventricular nucleus interactions: A bridge to the neuroendocrine and autonomic nervous system. Progr. Brain Res. 1988, 119, 365-382.

19. Klein, D.; Weller, J.; Moore, R. Melatonin metabolism: Neural regulation of pineal serotonin: Acetyl coenzyme A N-acetyltransferase activity. Proc. Natl. Acad. Sci. USA 1971, 68, 3107-3110. [CrossRef]

20. Krause, D.; Dubocovich, M. Regulatory sites in the melatonin system of mammals. Trends Neurosci. 1990, 13, 464-470. [CrossRef]

21. Maronde, E.; Stehle, J.H. The mammalian pineal gland: Known facts, unknown facets. Trends Endocrinol. Metab. 2007, 18, 142-149. [CrossRef]

22. Lüthen, H.; Ludwing-Müller, J. History of Plant Hormone Research. J. Plant Growth Regul. 2015, 34, 697-892.

23. Hattori, A.; Migitaka, H.; Iigo, M.; Yamamoto, K.; Ohtani-Kaneko, R.; Hara, M.; Suzuki, T.; Reiter, R.J. Identification of melatonin in plants and its effects on plasma melatonin levels and binding to melatonin receptors in vertebrates. Biochem. Mol. Biol. Int. 1995, 35, 627-634.

24. Dubbels, R.; Reiter, R.J.; Klenke, E.; Goebel, A.; Schnakenberg, E.; Ehlers, C.; Schiwara, H.W.; Schloot, W. Melatonin in edible plants identified by radioimmunoassay and by HPLC-MS. J. Pineal Res. 1995, 18, $28-31$. [CrossRef] [PubMed]

25. Kolar, J.; Machackova, I.; Illnerova, H.; Prinsen, E.; van Dongen, W.; van Onckelen, H. Melatonin in higher plant determined by radioimmunoassay and liquid chromatography-mass spectrometry. Biol. Rhythm Res. 1995, 26, 406-409.

26. Arnao, M.B. Phytomelatonin: Discovery, content, and role in plants. Adv. Bot. 2014, 2014, e815769. [CrossRef]

27. Kolar, J.; Machackova, I.; Eder, J.; Prinsen, E.; van Dongen, W.; van Onckelen, H.; Illnerova, H. Melatonin: Occurrence and daily rhythm in Chenopodium rubrum. Phytochemistry 1997, 44, 1407-1413. [CrossRef]

28. Wolf, K.; Kolar, J.; Witters, E.; van Dongen, W.; van Onckelen, H.; Machackova, I. Daily profile of melatonin levels in Chenopodium rubrum L. depends on photoperiod. J. Plant Physiol. 2001, 158, 1491-1493. [CrossRef]

29. Kolar, J.; Johnson, C.; Machackova, I. Exogenously applied melatonin affects flowering of the short-day plant Chenopodium rubrum. Physiol. Plant 2003, 118, 605-612. [CrossRef]

30. Kolar, J. Effects of Melatonin on Circadian Rhythms and Photoperiodism in Higher Plants. Ph.D. Thesis, Faculty of Natural Sciences, Charles University, Prague, Czechia, March 2003.

31. Murch, S.J.; KrishnaRaj, S.; Saxena, P.K. Tryptophan is a precursor for melatonin and serotonin biosynthesis in in vitro regenerated St. John's wort (Hypericum perforatum L.) plants. Plant Cell Rep. 2000, 19, 698-704. [CrossRef] [PubMed]

32. Murch, S.J.; Campbell, S.S.B.; Saxena, P.K. The role of serotonin and melatonin in plant morphogenesis. Regulation of auxin-induced root organogenesis in in vitro-cultured explants of Hypericum perforatum $\mathrm{L}$. In Vitro Cell. Dev. Biol. Plant 2001, 37, 786-793. [CrossRef]

33. Murch, S.J.; Saxena, P.K. Melatonin: A potential regulator of plant growth and development? In Vitro Cell. Dev. Biol. Plant 2002, 38, 531-536. [CrossRef] 
34. Hernández-Ruiz, J.; Cano, A.; Arnao, M.B. Melatonin: Growth-stimulating compound present in lupin tissues. Planta 2004, 220, 140-144. [CrossRef] [PubMed]

35. Hernández-Ruiz, J.; Cano, A.; Arnao, M.B. Melatonin acts as a growth-stimulating compound in some monocot species. J. Pineal Res. 2005, 39, 137-142. [CrossRef] [PubMed]

36. Arnao, M.B.; Hernández-Ruiz, J. The physiological function of melatonin in plants. Plant Signal. Behav. 2006, 1, 89-95. [CrossRef] [PubMed]

37. Lei, X.Y.; Zhu, R.Y.; Zhang, G.Y.; Dai, Y.R. Attenuation of cold-induced apoptosis by exogenous melatonin in carrot suspension cells: The possible involvement of polyamines. J. Pineal Res. 2004, 36, 126-131. [CrossRef]

38. Posmyk, M.M.; Kuran, H.; Marciniak, K.; Janas, K.M. Presowing seed treatment with melatonin protects red cabbage seedlings against toxic copper ion concentrations. J. Pineal Res. 2008, 45, 24-31. [CrossRef] [PubMed]

39. Posmyk, M.M.; Balabusta, M.; Wieczorek, M.; Sliwinska, E.; Janas, K.M. Melatonin applied to cucumber (Cucumis sativus L.) seeds improves germination during chilling stress. J. Pineal Res. 2009, 46, $214-223$. [CrossRef]

40. Arnao, M.B.; Hernández-Ruiz, J. Melatonin: Plant growth regulator and/or biostimulator during stress? Trends Plant Sci. 2014, 19, 789-797. [CrossRef]

41. Arnao, M.B.; Hernández-Ruiz, J. Functions of melatonin in plants: A review. J. Pineal Res. 2015, 59, $133-150$. [CrossRef] [PubMed]

42. Arnao, M.B.; Hernández-Ruiz, J. Melatonin: A new plant hormone and/or a plant master regulator? Trends Plant Sci. 2019, 24, 38-48. [CrossRef]

43. Debnath, B.; Islam, W.; Li, M.; Sun, Y.; Lu, X.; Mitra, S.; Hussain, M.; Liu, S.; Qiu, D. Melatonin mediates enhancement of stress tolerance in plants. Int. J. Mol. Sci. 2019, 20, 1040. [CrossRef] [PubMed]

44. Zhan, H.; Nie, X.; Zhang, T.; Li, S.; Wang, X.; Du, X.; Tong, W.; Weining, S. Melatonin: A small molecule but important for salt stress tolerance in plants. Int. J. Mol. Sci. 2019, 20, 709. [CrossRef] [PubMed]

45. Kul, R.; Esringü, A.; Dadasoglu, E.; Sahin, U.; Turan, M.; Örs, S.; Ekinci, M.; Agar, G.; Yildirim, E. Melatonin: Role in Increasing Plant Tolerance in Abiotic Stress Conditions. In Abiotic and Biotic Stress in Plants; De Oliveira, A., Ed.; IntechOpen: London, UK, 2019; pp. 1-19.

46. Wang, Y.; Reiter, R.J.; Chan, Z. Phytomelatonin: A universal abiotic stress regulator. J. Exp. Bot. 2018, 69, 963-974. [CrossRef] [PubMed]

47. Hernández-Ruiz, J.; Arnao, M.B. Relationship of melatonin and salicylic acid in biotic/abiotic plant stress responses. Agronomy 2018, 8, 33. [CrossRef]

48. Fan, J.; Xie, Y.; Zhang, Z.; Chen, L. Melatonin: A multifunctional factor in plants. Int. J. Mol. Sci. 2018, 19, 1528. [CrossRef] [PubMed]

49. Sharif, R.; Xie, C.; Zhang, H.; Arnao, M.B.; Ali, M.; Ali, Q.; Muhammad, I.; Shalmani, A.; Nawaz, M.; Chen, P.; et al. Melatonin and its effects on plant systems. Molecules 2018, 23, 2352. [CrossRef] [PubMed]

50. Kanwar, M.K.; Yu, J.; Zhou, J. Phytomelatonin: Recent advances and future prospects. J. Pineal Res. 2018, 65, e12526. [CrossRef]

51. Yu, Y.; Lv, Y.; Shi, Y.; Li, T.; Chen, Y.; Zhao, D.; Zhao, Z. The role of phyto-melatonin and related metabolites in response to stress. Molecules 2018, 23, 1887. [CrossRef]

52. Arnao, M.B.; Hernández-Ruiz, J. Melatonin promotes adventitious- and lateral root regeneration in etiolated hypocotyls of Lupinus albus L. J. Pineal Res. 2007, 42, 147-152. [CrossRef]

53. Arnao, M.B.; Hernández-Ruiz, J. Protective effect of melatonin against chlorophyll degradation during the senescence of barley leaves. J. Pineal Res. 2009, 46, 58-63. [CrossRef]

54. Wang, P.; Yin, L.; Liang, D.; Li, C.; Ma, F.; Yue, Z. Delayed senescence of apple leaves by exogenous melatonin treatment: Toward regulating the ascorbate-glutathione cycle. J. Pineal Res. 2012, 53, 11-20. [CrossRef] [PubMed]

55. Arnao, M.B.; Hernández-Ruiz, J. Chemical stress by different agents affects the melatonin content of barley roots. J. Pineal Res. 2009, 46, 295-299. [CrossRef] [PubMed]

56. Arnao, M.B.; Hernández-Ruiz, J. Melatonin in its relationship to plant hormones. Ann. Bot. 2018, 121, 195-207. [CrossRef] [PubMed]

57. Garrido, M.; Paredes, S.D.; Cubero, J.; Lozano, M.; Toribio-Delgado, A.F.; Muñoz, J.L.; Reiter, R.J.; Barriga, C.; Rodríguez, A.B. Jerte valley cherry-enriched diets improve nocturnal rest and increase 6-sulfatoxymelatonin 
and total antioxidant capacity in the urine of middle-aged and elderly humans. J. Gerontol. A Biol. Sci. Med. Sci. 2010, 65, 909-914. [CrossRef] [PubMed]

58. Garrido, M.; Espino, J.; González-Gómez, D.; Lozano, M.; Cubero, J.; Toribio-Delgado, A.F.; Maynar-Mariño, J.I.; Terrón, M.P.; Muñoz, J.L.; Pariente, J.A.; et al. A nutraceutical product based on Jerte Valley cherries improves sleep and augments the antioxidant status in humans. e-SPEN Eur. e-J. Clin. Nutr. Metab. 2009, 4, e321-e323. [CrossRef]

59. Oba, S.; Nakamura, K.; Sahashi, Y.; Hattori, A.; Nagata, C. Consumption of vegetables alters morning urinary 6-sulfatoxymelatonin concentration. J. Pineal Res. 2008, 45, 17-23. [CrossRef] [PubMed]

60. Maldonado, M.D.; Moreno, H.; Calvo, J.R. Melatonin present in beer contributes to increase the levels of melatonin and antioxidant capacity of the human serum. Clin. Nutr. 2009, 28, 188-191. [CrossRef]

61. Molfino, A.; Laviano, A.; Fanelli, F.R. Sleep-inducing effect of beer: A melatonin- or alcohol-mediated effect? Clin. Nutr. 2010, 29, 272. [CrossRef] [PubMed]

62. Chen, G.; Huo, Y.; Tan, D.X.; Liang, Z.; Zhang, W.; Zhang, Y. Melatonin in chinese medicinal herbs. Life Sci. 2003, 73, 19-26. [CrossRef]

63. Zohar, R.; Izhaki, I.; Koplovich, A.; Ben-Shlomo, R. Phytomelatonin in the leaves and fruits of wild perennial plants. Phytochem. Lett. 2011, 4, 222-226. [CrossRef]

64. Feng, X.; Wang, M.; Zhao, Y.; Han, P.; Dai, Y. Melatonin from different fruit sources, functional sources, and analytical methods. Trends Food Sci. Technol. 2014, 37, 21-31. [CrossRef]

65. Meng, X.; Li, Y.; Li, S.; Zhou, Y.; Gan, R.Y.; Xu, D.P.; Li, H.B. Dietary sources and bioactivities of melatonin. Nutrients 2017, 9, 367. [CrossRef] [PubMed]

66. Song, M.; Park, W.S.; Yoo, J.; Ham, J.S. The potential of melatonin for the application in dairy products. J. Milk Sci. Biotechnol. 2018, 36, 14-25. [CrossRef]

67. Arnao, M.B.; Hernández-Ruiz, J. The potential of phytomelatonin as a nutraceutical. Molecules 2018, $23,238$. [CrossRef] [PubMed]

68. Arnao, M.B.; Hernández-Ruiz, J. Phytomelatonin, natural melatonin from plants as a novel dietary supplement: Sources, activities and world market. J. Funct. Foods 2018, 48, 37-42. [CrossRef]

69. Arnao, M.B.; Hernández-Ruiz, J. Phytomelatonin versus synthetic melatonin in cancer treatments. Biomed. Res. Clin. Pract. 2018, 3. [CrossRef]

70. Salehi, B.; Sharopov, F.; Fokou, V.P.; Kobylinska, A.; Jonge, D.L.; Tadio, K.; Sharifi-Rad, J.; Posmyk, M.M.; Martorell, M.; Martins, N.; et al. Melatonin in medicinal and food plants: Occurrence, bioavailability, and health potential for humans. Cells 2019, 8, 681. [CrossRef] [PubMed]

71. Kang, S.; Kang, K.; Lee, K.; Back, K. Characterization of tryptamine 5-hydroxylase and serotonin synthesis in rice plants. Plant Cell Rep. 2007, 26, 2009-2015. [CrossRef] [PubMed]

72. Kang, S.; Kang, K.; Lee, K.; Back, K. Characterization of rice tryptophan decarboxylases and their direct involvement in serotonin biosynthesis in transgenic rice. Planta 2007, 227, 263-272. [CrossRef]

73. Kang, K.; Lee, K.; Park, S.; Kim, Y.S.; Back, K. Enhanced production of melatonin by ectopic overexpression of human serotonin $N$-acetyltransferase plays a role in cold resistance in transgenic rice seedlings. J. Pineal Res. 2010, 49, 176-182. [CrossRef]

74. Kang, K.; Kong, K.; Park, S.; Natsagdori, U.; Kim, Y.; Back, K. Molecular cloning of a plant N-acetylserotonin methyltransferase and its expression characteristics in rice. J. Pineal Res. 2011, 50, 304-309. [CrossRef] [PubMed]

75. Park, S.; Lee, K.; Kim, Y.S.; Back, K. Tryptamine 5-hydroxylase-deficient Sekiguchi rice induces synthesis of 5-hydroxytryptophan and $N$-acetyltryptamine but decreases melatonin biosynthesis during senescence process of detached leaves. J. Pineal Res. 2012, 52, 211-216. [CrossRef]

76. Kang, K.; Lee, K.; Park, S.; Byeon, Y.; Back, K. Molecular cloning of rice serotonin N-acetyltransferase, the penultimate gene in plant melatonin biosynthesis. J. Pineal Res. 2013, 55, 7-13. [CrossRef] [PubMed]

77. Park, S.; Byeon, Y.; Back, K. Functional analyses of three ASMT gene family members in rice plants. J. Pineal Res. 2013, 55, 409-415. [CrossRef]

78. Byeon, Y.; Lee, H.Y.; Lee, K.; Park, S.; Back, K. Cellular localization and kinetics of the rice melatonin biosynthetic enzymes SNAT and ASMT. J. Pineal Res. 2014, 56, 107-114. [CrossRef] [PubMed]

79. Byeon, Y.; Park, S.; Lee, H.Y.; Kim, Y.S.; Back, K. Elevated production of melatonin in transgenic rice seeds expressing rice tryptophan decarboxylase. J. Pineal Res. 2014, 56, 275-282. [CrossRef] [PubMed] 
80. Byeon, Y.; Choi, G.H.; Lee, H.Y.; Back, K. Melatonin biosynthesis requires N-acetylserotonin methyltransferase activity of caffeic acid O-methyltransferase in rice. J. Exp. Bot. 2015, 66, 6917-6925. [CrossRef]

81. Byeon, Y.; Lee, H.J.; Lee, H.Y.; Back, K. Cloning and functional characterization of the Arabidopsis $\mathrm{N}$-acetylserotonin $\mathrm{O}$-methyltransferase responsible for melatonin synthesis. J. Pineal Res. 2016, 60, 65-73. [CrossRef]

82. Choi, G.H.; Lee, H.Y.; Back, K. Chloroplast overexpression of rice caffeic acid O-methyltransferase increases melatonin production in chloroplasts via the 5-methoxytryptamine pathway in transgenic rice plants. J. Pineal Res. 2017, 62, e12412. [CrossRef]

83. Back, K.; Tan, D.X.; Reiter, R.J. Melatonin biosynthesis in plants: Multiple pathways catalyze tryptophan to melatonin in the cytoplasm or chloroplasts. J. Pineal Res. 2016, 61, 426-437. [CrossRef]

84. Byeon, Y.; Back, K. Molecular cloning of melatonin 2-hydroxylase responsible for 2-hydroxymelatonin production in rice (Oryza sativa). J. Pineal Res. 2015, 58, 343-351. [CrossRef] [PubMed]

85. Byeon, Y.; Tan, D.X.; Reiter, R.J.; Back, K. Predominance of 2-hydroxymelatonin over melatonin in plants. J. Pineal Res. 2015, 59, 448-454. [CrossRef] [PubMed]

86. Lee, K.; Zawadzka, A.; Czarnocki, Z.; Reiter, R.J.; Back, K. Molecular cloning of melatonin 3-hydroxylase and its production of cyclic 3-hydroxymelatonin in rice (Oryza sativa). J. Pineal Res. 2016, 61, 470-478. [CrossRef]

87. Lee, H.J.; Back, K. 2-Hydroxymelatonin promotes the resistance of rice plant to multiple simultaneous abiotic stresses (combined cold and drought). J. Pineal Res. 2016, 61, 303-316. [CrossRef] [PubMed]

88. Lee, H.J.; Back, K. 2-Hydroxymelatonin confers tolerance against combined cold and drought stress in tobacco, tomato, and cucumber as a potent anti-stress compound in the evolution of land plants. Functional role of 2-hydroxymelatonin in plants. Melatonin Res. 2019, 2, 35-46. [CrossRef]

89. Lee, K.; Choi, G.H.; Back, K. Cadmium-induced melatonin synthesis in rice requires light, hydrogen peroxide, and nitric oxide: Key regulatory roles for tryptophan decarboxylase and caffeic acid $O$-methyltransferase. J. Pineal Res. 2017, 63, e12441. [CrossRef] [PubMed]

90. Pelagio-Flores, R.; Muñoz-Parra, E.; Ortiz-Castro, R.; Lopez-Bucio, J. Melatonin regulates Arabidopsis root system architecture likely acting independently of auxin signaling. J. Pineal Res. 2012, 53, 279-288. [CrossRef]

91. Arnao, M.B.; Hernández-Ruiz, J. Growth conditions influence the melatonin content of tomato plants. Food Chem. 2013, 138, 1212-1214. [CrossRef]

92. Arnao, M.B.; Hernández-Ruiz, J. Growth conditions determine different melatonin levels in Lupinus albus L. J. Pineal Res. 2013, 55, 149-155. [CrossRef]

93. Byeon, Y.; Park, S.; Kim, Y.S.; Back, K. Microarray analysis of genes differentially expressed in melatonin-rich transgenic rice expressing a sheep serotonin N-acetyltransferase. J. Pineal Res. 2013, 55, 357-363. [PubMed]

94. Zhang, N.; Zhang, H.J.; Zhao, B.; Sun, Q.Q.; Cao, Y.Y.; Li, R.; Wu, X.X.; Weeda, S.; Li, L.; Ren, S.; et al. The RNA-seq approach to discriminate gene expression profiles in response to melatonin on cucumber lateral root formation. J. Pineal Res. 2014, 56, 39-50. [CrossRef]

95. Sarropoulou, V.N.; Dimassi-Theriou, K.N.; Therios, I.N.; Koukourikou-Petridou, M. Melatonin enhances root regeneration, photosynthetic pigments, biomass, total carbohydrates and proline content in the cherry rootstock PHL-C (Prunus avium $x$ Prunus cerasus). Plant Physiol. Biochem. 2012, 61, 162-168. [CrossRef]

96. Zhang, N.; Zhao, B.; Zhang, H.J.; Weeda, S.; Yang, C.; Yang, Z.C.; Ren, S.; Guo, Y.D. Melatonin promotes water-stress tolerance, lateral root formation, and seed germination in cucumber (Cucumis sativus L.). J. Pineal Res. 2013, 54, 15-23. [CrossRef] [PubMed]

97. Wang, P.; Sun, X.; Li, C.; Wei, Z.; Liang, D.; Ma, F. Long-term exogenous application of melatonin delays drought-induced leaf senescence in apple. J. Pineal Res. 2013, 54, 292-302. [CrossRef]

98. Lazar, D.; Murch, S.J.; Beilby, M.J.; Al Khazaaly, S. Exogenous melatonin affects photosynthesis in characeae Chara australis. Plant Sign. Behav. 2013, 8, e23279. [CrossRef] [PubMed]

99. Li, C.; Wang, P.; Wei, Z.; Liang, D.; Jia, D.; Fu, M.; Ma, F. The mitigation effects of exogenous melatonin on salinity-induced stress in Malus hupehensis. J. Pineal Res. 2012, 53, 298-306. [CrossRef] [PubMed]

100. Zhao, N.; Sun, Y.; Wang, D.Y.; Zheng, J.X. Effects of exogenous melatonin on nitrogen metabolism in cucumber seedlings under high temperature stress. Plant Physiol. Commun. 2012, 48, 557-564.

101. Shi, H.; Ye, T.; Chan, Z. Exogenous application of hydrogen sulfide donor sodium hydrosulfide enhanced multiple abiotic stress tolerance in bermudagrass (Cynodon dactylon (L). Pers.). Plant Physiol. Biochem. 2013, 71, 226-234. [CrossRef] [PubMed] 
102. Yin, L.; Wang, P.; Li, M.; Ke, X.; Li, C.; Liang, D.; Wu, S.; Ma, X.; Li, C.; Zou, Y.; et al. Exogenous melatonin improves Malus resistance to Marssonina apple blotch. J. Pineal Res. 2013, 54, 426-434. [CrossRef]

103. Lee, H.Y.; Byeon, Y.; Back, K. Melatonin as a signal molecule triggering defense responses against pathogen attack in Arabidopsis and tobacco. J. Pineal Res. 2014, 57, 262-268. [CrossRef] [PubMed]

104. Weeda, S.; Zhang, N.; Zhao, X.; Ndip, G.; Guo, Y.D.; Buck, G.; Fu, C.; Ren, S. Arabidopsis transcriptome analysis reveals key roles of melatonin in plant defense systems. PLoS ONE 2014, 9, e93462. [CrossRef] [PubMed]

105. Bajwa, V.S.; Shukla, M.R.; Sherif, S.M.; Murch, S.J.; Saxena, P.K. Role of melatonin in alleviating cold stress in Arabidopsis thaliana. J. Pineal Res. 2014, 56, 238-245. [CrossRef]

106. Shi, H.; Chan, Z. The Cysteine2/Histidine2-type transcription factor ZINC FINGER OF ARABIDOPSIS THALIANA 6-activated C-REPEAT-BINDING FACTOR pathway is essential for melatonin-mediated freezing stress resistance in Arabidopsis. J. Pineal Res. 2014, 57, 185-191. [CrossRef]

107. Zhang, H.J.; Zhang, N.; Yang, R.C.; Wang, L.; Sun, Q.Q.; Li, D.B.; Cao, Y.Y.; Weeda, S.; Zhao, B.; Ren, S.; et al. Melatonin promotes seed germination under high salinity by regulating antioxidant systems, ABA and GA4 interaction in cucumber (Cucumis sativus L.). J. Pineal Res. 2014, 57, 269-279. [CrossRef] [PubMed]

108. Li, C.; Liang, D.; Chang, C.; Jia, D.; Ma, F. Melatonin mediates the regulation of ABA metabolism, free-radical scavenging, and stomatal behavior in two Malus species under drought stress. J. Exp. Bot. 2015, 66, 669-680. [CrossRef] [PubMed]

109. Shi, H.; Chen, Y.; Tan, D.X.; Reiter, R.J.; Chan, Z.; He, C. Melatonin induces nitric oxide and the potential mechanisms relate to innate immunity against bacterial pathogen infection in Arabidopsis. J. Pineal Res. 2015, 59, 102-108. [CrossRef]

110. Wei, Y.; Zeng, H.; Hu, W.; Chen, L.; He, C.; Shi, H. Comparative transcriptional profiling of melatonin synthesis and catabolic genes indicates the possible role of melatonin in developmental and stress responses in rice. Front. Plant Sci. 2016, 7, 676. [CrossRef]

111. Shi, H.; Wei, Y.; He, C. Melatonin-induced CBF/DREB1s are essential for diurnal change of disease resistance and CCA1 expression in Arabidopsis. Plant Physiol. Biochem. 2016, 100, 150-155. [CrossRef]

112. Sun, Q.Q.; Zhang, N.; Wang, J.; Zhang, H.J.; Li, D.B.; Shi, J.; Li, R.; Weeda, S.; Zhao, B.; Ren, S.; et al. Melatonin promotes ripening and improves quality of tomato fruit during postharvest life. J. Exp. Bot. 2015, 66, 657-668. [CrossRef] [PubMed]

113. Aghdam, M.S.; Fard, J.R. Melatonin treatment attenuates postharvest decay and maintains nutritional quality of strawberry fruits (Fragaria x anannasa cv. Selva) by enhancing GABA shunt activity. Food Chem. 2017, 221, 1650-1657. [CrossRef] [PubMed]

114. Gao, H.; Zhang, Z.K.; Chai, H.K.; Cheng, N.; Yang, Y.; Wang, D.N.; Yang, T.; Cao, W. Melatonin treatment delays postharvest senescence and regulates reactive oxygen species metabolism in peach fruit. Postharvest Biol. Technol. 2016, 118, 103-110. [CrossRef]

115. Aghdam, M.S.; Jannatizadeh, A.; Nojadeh, M.S.; Ebrahimzadeh, A. Exogenous melatonin ameliorates chilling injury in cut anthurium flowers during low temperature storage. Postharvest Biol. Technol. 2019, 148, 184-191. [CrossRef]

116. Liu, J.; Zhai, R.; Liu, F.; Zhao, Y.; Wang, H.; Liu, L.; Yang, C.; Wang, Z.; Ma, F.; Xu, L. Melatonin induces parthenocarpy by regulating genes in gibberellin pathways in 'Starkrimson' pear (Pyrus communis L.). Front. Plant Sci. 2018, 9, 946. [CrossRef] [PubMed]

117. Wei, J.; Li, D.; Zhang, J.; Shan, C.; Rengel, Z.; Song, Z.; Chen, Q. Phytomelatonin receptor PMTR1-mediated signaling regulates stomatal closure in Arabidopsis thaliana. J. Pineal Res. 2018, 65, e12500. [CrossRef]

118. Chen, L.; Wang, M.R.; Li, J.W.; Feng, C.H.; Cui, Z.H.; Zhao, L.; Wang, Q.C. Exogenous application of melatonin improves eradication of apple stem grooving virus from the infected in-vitro shoots by shoot tip culture. Plant Pathol. 2019, 68, 997-1006. [CrossRef]

119. Arnao, M.B.; Hernández-Ruiz, J. Growth activity, rooting capacity, and tropism: Three auxinic precepts fulfilled by melatonin. Acta Physiol. Plant. 2017, 39, 127. [CrossRef]

120. Arnao, M.B.; Hernández-Ruiz, J. The multi-regulatory properties of melatonin in plants. In Neurotransmitters in Plants; Roshchina, V.V., Ramakrishna, A., Eds.; Taylor \& Francis-CRC: New York, NY, USA, 2018; pp. 71-101.

121. Shibaeva, T.G.; Markovskaya, E.F.; Mamaev, A.V. Phytomelatonin: A review. Biol. Bull. Rev. 2018, 8, 375-388. [CrossRef] 
122. Erland, L.A.E.; Saxena, P.K. Melatonin in plant morphogenesis. In Vitro Cell. Dev. Biol. Plant 2018, 54, 3-24. [CrossRef]

123. Mukherjee, S. Recent advancements in the mechanism of nitric oxide signaling associated with hydrogen sulfide and melatonin crosstalk during ethylene-induced fruit ripening in plants. Nitric Oxide 2019, 82, $25-34$. [CrossRef]

124. Arnao, M.B.; Hernández-Ruiz, J. Melatonin and reactive oxygen and nitrogen species: A model for the plant redox network. Melatonin Res. 2019, 2, 152-168. [CrossRef]

(C) 2020 by the authors. Licensee MDPI, Basel, Switzerland. This article is an open access article distributed under the terms and conditions of the Creative Commons Attribution (CC BY) license (http://creativecommons.org/licenses/by/4.0/). 